\title{
OPPRESSION OR DERIVATIVE? GREATER ClARITY THROUGH THE REQUIREMENT FOR DIRECT HARM
}

\author{
JORDON MAGICO*
}

In this article, the author seeks to discern the limits of the broadly scoped oppression action. The author first discusses the oppression and derivative actions and their purposes, and then argues that the oppression provision does not embrace derivative harm. Using the recent Supreme Court of Canada decision in Brunette, the author reinforces the requirement of direct injury distinct from that suffered by the corporation, when bringing a personal action. The author then examines case law in pursuit of clarity about what constitutes direct harm and whether it is difficult to demonstrate. The author concludes by recommending that the Supreme Court clarify the distinction between oppression and derivative actions by integrating the direct harm requirement into the test for oppression.

\section{TABLE OF CONTENTS}

I. INTRODUCTION . . . . . . . . . . . . . . . . . . . . 817

II. DERIVATIVE AND OPPRESSION ACTIONS $\ldots \ldots \ldots \ldots \ldots \ldots \ldots \ldots . \ldots . \ldots . \ldots . \ldots$

A. The OPPRESSION ACTION AND ITS PURPOSE . . . . . . . . . . . . 819

B. The Derivative Action AND ITS Purpose $\ldots \ldots \ldots \ldots . \ldots . \ldots 820$

C. Can a Derivative Claim Proceed

BY WAY OF AN OPPRESSION ACTION? . . . . . . . . . . . . . . . 821

III. The SuPreme Court of CANADA DeCISION IN BRUNETTE . . . . . . . . . 829

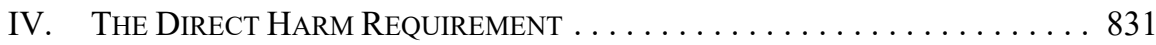

A. Drop In The VAlue of SHares $\ldots \ldots \ldots \ldots \ldots \ldots \ldots$

B. SQUEEZING OUT A MINORITY SHAREHOLDER

(NON-PAYMENT OF DIVIDENDS) . . . . . . . . . . . 834

C. Failing to Disclose Related Party Transactions . . . . . . 835

D. ExcESSIVE MANAGEMENT FEeS $\ldots \ldots \ldots \ldots \ldots \ldots \ldots$

V. CONCLUSION .......................... 837

[W] hat constitutes fairness is, like beauty, to be found in the eye of the beholder. ${ }^{1}$

Having chosen to receive the benefits of incorporation, he should not be allowed to escape its burdens. He should not be permitted to "blow hot and cold" at the same time. ${ }^{2}$

\section{INTRODUCTION}

The oppression action is an extraordinarily flexible and comprehensive action designed to respond to an infinite number of possibilities in a corporate relationship. One commentator has described the oppression remedy as "the broadest, most comprehensive and most open-

JD Candidate (2020), BCom (2017), University of Alberta. The author wishes to thank Professor Shannon O'Byrne for her invaluable guidance, as well as the two anonymous reviewers for their comments and suggestions to improve the quality of this article.

Re Webb and Ontario Housing Corp (1978), 22 OR (2d) 257 at 266 (CA).

Kosmopoulos $v$ Constitution Insurance Co, [1987] 1 SCR 2 at 11 [Kosmopoulous]. 
ended shareholder remedy in the common law world."33 Likewise, the Supreme Court of Canada has emphasized the breadth of the oppression remedy. ${ }^{4}$ However, accompanying the oppression action's wide ambit is the need to discern its limits.

More specifically, there is uncertainty surrounding what claims may be brought under the oppression action and what must be advanced derivatively. ${ }^{5}$ In other words, is a stakeholder permitted to bring a personal oppression claim for harm done to the corporation? Or must the corporation pursue an action for harm committed against it?

The purpose of this article is to show that an oppression action cannot be brought for harm suffered primarily by the corporation. Rather, the bulk of the authority suggests that to pursue a personal oppression remedy, a complainant must show direct harm that is distinct from that suffered by the corporation.

To support this position, this article is divided into several parts. Part II begins by providing a brief introduction to both the Canada Business Corporations Act ${ }^{6}$ oppression and derivative provisions. It then goes on to examine whether the oppression provision embraces derivative harm. Ultimately, the argument that a derivative claim cannot be brought by way of oppression appears more persuasive. Part III supports this position by summarizing the recent Supreme Court decision in Brunette v. Legault Joly Thiffault, s.e.n.c.r.l., ${ }^{7}$ which emphasized the need for direct harm when bringing a personal action. The requirement for direct harm is further explored in Part IV, where a sample of Canadian case law is categorized and examined. This article concludes by recommending, absent a statutory amendment, that the Supreme Court expressly integrate the direct harm requirement into the judicial test for oppression. This will lead to a clearer distinction between oppression and derivative actions, which in turn will import a greater degree of certainty into this area of the law. Such a development would only provide long-term benefits for corporate stakeholders. ${ }^{8}$

\section{DERIVATIVE AND OPPRESSION ACTIONS}

This Part begins by briefly introducing the statutory oppression and derivative actions, respectively. Next, arguments in favour of the oppression provision embracing derivative claims are outlined. Following this, arguments that derivative claims cannot proceed by way of oppression are illustrated and ultimately endorsed.

Stanley M Beck, "Minority Shareholders' Rights in the 1980s" in Special Lectures of the Law Society of Upper Canada: Corporate Law in the 80s (Don Mills, ON: Richard De Boo, 1982) 311 at 312.

See Peoples Department Stores Inc (Trustee of) $v$ Wise, 2004 SCC 68 at para 51; BCE Inc v 1976 Debentureholders, 2008 SCC 69 at paras 58, 119 [BCE].

Kevin Patrick McGuinness, Canadian Business Corporations Law, 3rd ed, vol 3 (Toronto: LexisNexis, 2017) (" $[\mathrm{t}]$ he distinction between a personal wrong and a wrong to the corporation can be exceedingly fine" at § 22.45); Markus Koehnen, Oppression and Related Remedies (Toronto: Thomson Carswell, 2004) ("[h]owever one expresses it, the distinction between derivative actions and oppression complaints remains murky" at 443); Rea $v$ Wildeboer, 2015 ONCA 373 at paras 20, 28 [Rea]. Although beyond the scope of this article, it should be noted that an oppression action may be viewed as more favourable due to the derivative action's leave requirement and associated procedures, outlined briefly below.

RSC 1985, c C-44 [CBCA]. Unless stated otherwise, the statute examined in this article is the CBCA. 2018 SCC 55 [Brunette].

McGuinness, supra note 5 ("vague rules of uncertain application increase transaction costs... In any area of law so closely tied to the health of the national economy as corporate law, there is an obvious benefit in rules of law that are clear in their meaning and predictable in their outcome" at $\S \S 21.692-93$ ). 


\section{A. The Oppression ACtion And its Purpose}

The oppression action is statutory in nature, and confers upon a court a high degree of discretion to make any "order it thinks fit." The provision departs from the traditional common law approach, which favoured majority rule, and instead favours minority protection. ${ }^{10}$ In doing so, the oppression action recognizes that even majority conduct that is entirely lawful can be harmful to minority stakeholders. ${ }^{11}$ Indeed, it "advances the insight that majority conduct ... can be unscrupulous and egregious even while staying within the strict, black-and-white-letter lines of legality." $" 2$ This is supported by the text of the provision, which protects "interests" rather than "rights." ${ }^{13}$ In short, the oppression remedy looks behind corporate formalities to analyze the substance of relationships and effects of corporate action. ${ }^{14}$

The Supreme Court in BCE provides the leading test for oppression. First, "[d]oes the evidence support the reasonable expectation asserted by the claimant? and [second, does] the evidence establish that the reasonable expectation was violated by conduct falling within the terms 'oppression,' 'unfair prejudice' or 'unfair disregard' of a relevant interest?" 15 BCE also confirmed that reasonable expectations, rather than strict legalities, are the "cornerstone" of the oppression remedy. ${ }^{16}$

While $B C E$ purported to clarify the test for oppression, an important element of the action was omitted and as a result, the provision remains unclear. ${ }^{17}$ Indeed, as McGuinness notes, "the case law often leaves prospective complainants uncertain as to whether they are entitled to relief under the oppression remedy or not.... Potential defendants are in no better a position." 18 Another commentator similarly highlights a downfall of the oppression

CBCA, supra note 6, s 241(3). For the full text of the provision, see Part II.C.1.a, below. See McEwen $v$ Goldcorp Inc, 2006 CanLII 35985 at para 42 (Ont Sup Ct J); First Edmonton Place Ltd v 315888 Alberta Ltd, 1988 CanLII 168 (Alta QB); Robert WV Dickerson, John L Howard \& Leon Getz, Proposals for a New Business Corporations Law for Canada, vol 1 (Ottawa: Information Canada, 1971) at para 23 [Dickerson Report].

$10 \quad$ See e.g. Re Winnipeg Saddlery Limited (1934), 42 Man R 448 (KB) (“"[m]ight is right” at 458); Cooper $v$ Gordon (1869), LR 8 Eq 249 ("[t]his Court would be very slow to interfere, and more probably would not interfere at all, with the discretion of the majority" at 258). See also Dennis H Peterson, Shareholder Remedies in Canada (Markham, ON: LexisNexis, 2009) (loose-leaf) ("[t]he oppression remedy may be considered the Charter of Rights and Freedoms of corporate law" at $\S 17.1$ ); Shannon Kathleen O'Byrne \& Cindy A Schipani, "Feminism(s), Progressive Corporate Law, and the Corporate Oppression Remedy: Seeking Fairness and Justice" (2017) 19:1 Geo J Gender \& L 61 at 88, 104.

11 The stakeholders who may bring an oppression action are numerous. See J Anthony VanDuzer, "Who May Claim Relief from Oppression: The Complainant in Canadian Corporate Law" (1993) 25:3 Ottawa L Rev 463.

12 O’Byrne \& Schipani, supra note 10 at 64 . See also BCE, supra note 4 at paras 58, 71; Naneff $v$ ConCrete Holdings Limited (1995), 23 OR (3d) 481 at paras 28-29 (CA); Korolis v Koutouki Taverna Saskatoon Inc, 2010 SKQB 183 at para 29; Linamar Corp v Wescast Industries Inc, 2004 CanLII 18045 at para 7 (Ont Sup Ct J).

13 CBCA, supra note 6, s 241(2); Re Ferguson and Imax Systems Corp (1983), 43 OR (2d) 128 at 140 (CA) [Ferguson].

14 Downtown Eatery (1993) Ltd v R (2001), 54 OR (3d) 161 at 183-84 (CA) [Downtown Eatery], leave to appeal to the SCC refused, [2002] 3 SCR vi (note).

15 BCE, supra note 4 at para 68. See Jassmine Girgis, "The Oppression Remedy: Clarifying Part II of the BCE Test” (2018) 96:3 Can Bar Rev 484 at 494. See also Wilson v Alharayeri, 2017 SCC 39 at paras $42-43$ [Wilson]; Downtown Eatery, ibid; CBCA, supra note 6, s 241(2).

BCE, supra note 4 at para 61 .

See Part IV, below.

McGuinness, supra note 5 at $\S \S 21.690-91$. See also Mohamed F Khimji \& Jon Viner, "Oppression Reducing Canadian Corporate Law to a Muddy Default" (2016) 47:1 Ottawa L Rev 127; Girgis, supra note 15 at 488 . 
provision, stating, “the oppression action's single, largest deficiency concerns cost: litigation is the only way to pursue a remedy and that [is] generally an expensive - even prohibitively expensive - proposition." "19 This uncertainty is a primary criticism of the oppression provision, and therefore further steps must be taken to clarify this area of the law.

\section{B. The Derivative ACtion and its Purpose}

Like oppression, the derivative action plays a fundamental role in corporate governance. ${ }^{20}$ The seminal decision of Salomon $v$. Salomon ${ }^{21}$ recognized the separate legal existence of a corporation. This concept is confirmed by the $C B C A$, which states: "A corporation has the capacity and, subject to this Act, the rights, powers and privileges of a natural person." ${ }^{22} \mathrm{~A}$ vehicle for exercising these rights is supplied by the derivative provision.

Traditionally, and owing to the rule in Foss v. Harbottle, shareholder recourse was notoriously limited. The Supreme Court in Hercules Managements Ltd. v. Ernst \& Young summarized the rule in Foss $v$. Harbottle as providing "that individual shareholders have no cause of action in law for any wrongs done to the corporation and that if an action is to be brought in respect of such losses, it must be brought . . . by the corporation itself (through management)." ${ }^{23}$ Today, while the rule in Foss $v$. Harbottle is still the law, it is functionally eclipsed by the statutory derivative action. ${ }^{24}$

The derivative provision fulfills several recognized policy objectives. ${ }^{25}$ First, it minimizes the possibility of strike suits and actions that seek to fulfill private vendettas. ${ }^{26}$ Second, the provision eliminates the possibility of numerous plaintiffs commencing separate actions for the same wrong (multiplicity of proceedings). ${ }^{27}$

To advance a statutory derivative action, the applicant must first establish standing by falling within the definition of a "complainant." ${ }^{28} \mathrm{Next}$, section 239 requires the complainant to show that: (1) reasonable notice was given to the directors, (2) the applicant is acting in good faith, and (3) the proposed action is in the "interests" of the corporation. ${ }^{29}$ The onus is

O’Byrne \& Schipani, supra note 10 at 109 . See also McGuinness, supra note 5 at $§ \S 21.702-703$ ("who can afford so much justice?" at $\S 21.703$ ).

See e.g. Richardson Greenshields of Canada Limited v Kalmacoff (1995), 22 OR (3d) 577 at 588 (CA); MA Maloney, "Whither the Statutory Derivative Action?” (1986) 64:2 Can Bar Rev 309.

[1896] UKHL 1.

CBCA, supra note $6, \mathrm{~s} 15(1)$ [emphasis added].

[1997] 2 SCR 165 at para 59 [Hercules].

Heath $v$ Mercantile Finance Service Ltd, 2015 PECA 11 at para 17.

See also Part II.C.2.b, below.

See Dickerson Report, supra note 9 at para 482; Jeffrey G MacIntosh, "The Oppression Remedy: Personal or Derivative?" (1991) 70:1 Can Bar Rev 29 at 63. MacIntosh ultimately concludes that the derivative and oppression provisions should be collapsed into one cause of action. Absent this, however, he holds that harm to the corporation should be addressed through the derivative action.

Hercules, supra note 23 (the derivative action is "sound from a policy perspective, inasmuch as it avoids the procedural hassle of a multiplicity of actions" at para 59); Rea, supra note 5 at para 37.

$C B C A$, supra note 6 (apart from those listed in (a)-(c), a complainant includes "any other person who, in the discretion of a court, is a proper person to make an application under this Part," s 238(d)); Re Daon Development Corporation (1984), 54 BCLR (2d) 235 at 242-44 (SC).

CBCA, supra note 6, s 239:

(1) Subject to subsection (2), a complainant may apply to a court for leave to bring an action in the name and on behalf of a corporation or any of its subsidiaries, or intervene in an action to which any such body corporate is a party, for the purpose of prosecuting, defending or discontinuing the action on behalf of the body corporate.

(2) No action may be brought and no intervention in an action may be made under subsection (1) 
on the applicant to "show that there is a prima facie case." ${ }^{30}$ If this statutory test is met, the court will permit the action in the name of the corporation.

\section{Can a Derivative Claim Proceed BY WAY OF AN OPPRESSION ACTION?}

\section{THE OPPRESSION PROVISION EMBRACES DERIVATIVE HARM}

\section{a. Statutory Analysis}

The text of the oppression provision suggests an argument that it embraces derivative harm. The starting point when analyzing statutory provisions is "the ordinary meaning as understood by the reader" because this "is assumed to correspond with the meaning intended by the writer." ${ }^{31}$ In other words, the provision is assumed to speak for itself. Section 241 reads, in part:

(1) A complainant may apply to a court for an order under this section.

(2) If, on an application under subsection (1), the court is satisfied that in respect of a corporation or any of its affiliates

(a) any act or omission of the corporation or any of its affiliates effects a result,

(b) the business or affairs of the corporation or any of its affiliates are or have been carried on or conducted in a manner, or

(c) the powers of the directors of the corporation or any of its affiliates are or have been exercised in a manner

that is oppressive or unfairly prejudicial to or that unfairly disregards the interests of any security holder, creditor, director or officer, the court may make an order to rectify the matters complained of.

(3) In connection with an application under this section, the court may make any interim or final order it thinks fit. ${ }^{32}$

unless the court is satisfied that

(a) the complainant has given notice to the directors of the corporation or its subsidiary of the complainant's intention to apply to the court under subsection (1) not less than fourteen days before bringing the application, or as otherwise ordered by the court, if the directors of the corporation or its subsidiary do not bring, diligently prosecute or defend or discontinue the action;

(b) the complainant is acting in good faith; and

(c) it appears to be in the interests of the corporation or its subsidiary that the action be brought, prosecuted, defended or discontinued. IGM Resources Corp v 979708 Alberta Ltd, 2004 ABQB 925 at para 30. See also Long v Spill-Sorb Canada Inc, 2010 ABQB 24 at para 12. See generally Maloney, supra note 20.

31 Ruth Sullivan, Sullivan on the Construction of Statutes, 6th ed (Markham, ON: LexisNexis, 2014) at $\S$ 3.5.

32 CBCA, supra note $6, \mathrm{~s} 241$ [emphasis added]. 
The provision alone discloses no requirement that peculiar harm be suffered by the complainant because the term "any" suggests that an entire class of corporate stakeholders could bring separate, individual actions. ${ }^{33}$ Similarly, the oppression provision appears to embrace both harm inflicted on the corporation and on the complainant. This is because harm to the corporation could concurrently be oppressive, be unfairly prejudicial, or unfairly disregard the interests of a stakeholder. The provision makes no distinction between personal and corporate harm.

Koehnen acknowledges that the "distinction between derivative and personal actions continues to make sense outside of the context of oppression claims." 34 However, this distinction is purportedly modified by the CBCA because the oppression provision "embraces both personal and corporate harm." 35 In other words, the text of the oppression provision does not preclude a derivative claim being advanced by way of oppression. Furthermore, the Dickerson Report states that when dealing with a "borderline case .... the aggrieved person may select the remedy that will best resolve his problem." ${ }^{36}$ As a result, the oppression provision has been interpreted by some courts as embracing derivative harm.

The Court in the early decision of Ontario (Securities Commission) v. McLaughlin addressed the provisions by stating, "[i]n all candour I cannot see that these provisions are mutually exclusive; they appear to me to be complementary, giving the applicants a choice of remedy." ${ }^{37}$ In another decision, an Ontario Court similarly held that "[t]he presence of a derivative action remedy does not preclude minority shareholders from pursuing their personal remedy under s. 241. The two are not mutually exclusive." ${ }^{38}$ In so holding, the complainants were permitted to advance an oppression claim for harm that was borne primarily by the corporation. ${ }^{39}$

The Ontario Court of Appeal in Malata Group (HK) Limited v. Jung viewed it as "stating the obvious to say that [the oppression provision] is drawn in broad language, both in terms of the harms it addresses and the non-exhaustive list of remedies it contemplates. ${ }^{, 40}$ In concluding that the oppression action could advance derivative claims, the Court reasoned that:

[A]llowing s. 248 oppression claims to proceed where there is harm to the corporation would not nullify s. 246 , because the two sections involve different threshold tests. Section 246 simply requires a violation of the corporation's legal rights. On the other hand, s. 248 requires, in the case of harm to the corporation, a

33

Angus Stevenson, ed, Oxford Dictionary of English (New York: Oxford University Press, 2010) sub verbo "any": "used to refer to one or some of a thing or number of things, no matter how much or how many.'

Koehnen, supra note 5 at 445.

Ibid at 445-46.

Dickerson Report, supra note 9 at para 484.

[1987] OJ No 1247 (QL) (H Ct J).

Ford Motor Co of Canada, Limited v Ontario (Municipal Employees Retirement Board), 2004 CanLII 34322 at para 241 (Ont Sup Ct J) [Ford Motor].

See David S Morritt, Sonia L Bjorkquist \& Allan D Coleman, The Oppression Remedy (Aurora, ON: Canada Law Book, 2004) (loose-leaf) at 7-19. See also Deluce Holdings Inc v Air Canada (1992), 12 OR (3d) 131 at 164-65 (Ct J (Gen Div)); Tersigni $v$ Georgevitch, 2015 ONSC 1454 at paras 29, 32 [Tersigni].

40

2008 ONCA 111 at para 29 [Malata]. See also Buccilli v Pillitteri, 2012 ONSC 6624 at para 190. 
violation of corporate legal rights that is oppressive or unfairly prejudicial, or that unfairly disregards the complainant's interests. ${ }^{41}$

It appears that the oppression provision was viewed as imposing a higher bar for the plaintiff to meet. From this, it follows that the derivative action would be preserved because complainants would continue to utilize its purportedly lower legal threshold. However, and as detailed later, this statement of the law is problematic because oppression involves a lower threshold test by merely examining reasonable expectations. ${ }^{42}$

Finally, the oppression remedies may be interpreted as supporting the proposition that the oppression provision embraces derivative harm. Section 241(3)(h) provides that a court may make "an order varying or setting aside a transaction or contract to which a corporation is a party and compensating the corporation or any other party to the transaction or contract."43 Such a remedy, if awarded to the corporation, arguably indicates that the harm was derivative in nature because the corporation benefited from the legal action. ${ }^{44}$

Similarly, by allowing a complainant to bring an action against an affiliated corporation, the oppression provision appears at first to ignore the historical distinction between the two actions. ${ }^{45}$ This is because "[t]he harm is twice removed from the plaintiff and would traditionally have been derivative. ${ }^{\prime 46}$ Permission to bring a legal claim against an affiliate perhaps indicates a legislative intention to ignore the distinction between the two actions.

However, such arguments ignore the fact that oppression remedies are inclusive rather than exhaustive. Making an order that benefits the corporation or allowing a complainant to proceed against an affiliate are merely examples that reflect courts' broad discretion to fashion remedies. ${ }^{47}$ The intention to confer broad remedial discretion is expressed in the Dickerson Report, which stated: "[S] ubsection (3) ensures that the court has broad powers to carry out its very comprehensive mandate under subsection (2). Some of these powers are novel. But they have one common object: to enable the court to apply a remedy that will offer continuing relief or indemnity to the complainant." 48 While the oppression remedies may appear to address derivative harm, the more accurate view is that they simply reinforce the broad judicial discretion granted for the purpose of resolving corporate disputes.

Focusing on the text of the oppression provision, it appears at first to support the argument that derivative claims can be advanced by way of oppression. While this position appears to give the complainant greater flexibility in how to proceed, it disregards the existence of the

Malata, ibid at para 34. See also Tersigni, supra note 39 at para 22.

See Part II.C.2.a, below.

CBCA, supra note 6, s 241(3)(h).

Malata, supra note 40 at para 29.

CBCA, supra note 6, s 241(2); Koehnen, supra note 5 at 446; MacIntosh, supra note 26 at 43.

Koehnen, ibid at 446.

See Dickerson Report, supra note 9 at para 484; Wilson, supra note 15 at para 26; 820099 Ontario Inc $\checkmark$ Harold E Ballard Ltd, [1991] OJ No 266 (QL) (Ct J (Gen Div)) [Ballard]. For cases where section 241(3)(h) is utilized, see $R v$ Sands Motor Hotel Limited, [1985] 1 WWR 59 (Sask QB); Low v Ascot Jockey Club Limited (1986), 1 BCLR (2d) 123 (SC).

Dickerson Report, ibid at para 486. Modern corporate law was driven in part by the report prepared by the Dickerson Committee as the CBCA largely adopted the contents of the two-volume Dickerson Report. The report illuminates the purposes and rationales behind many $C B C A$ provisions, and therefore serves as a useful tool when discerning legislative intent. 
derivative action and how the two actions relate to each other. In sum, if a complainant wishes to successfully allege oppression, they are required to show direct harm that is distinct from that suffered by the corporation. ${ }^{49}$

\section{b. The Size or Nature of the Corporation is Relevant}

Some courts place emphasis on the nature or size of the corporation when attempting to discern the distinction between derivative and oppression claims. In Malata, it was recognized that:

In disputes involving closely held companies with relatively few shareholders, such as the case at bar ... there is less reason to require the plaintiff to seek leave of the court. The small number of shareholders minimizes the risk of frivolous lawsuits against the corporation, thus weakening the main rationale for requiring a claim to proceed as a derivative action. ${ }^{50}$

Logically, the risk of multiple proceedings arising from the same harm is reduced when there are fewer stakeholders. The risk of strike suits is likewise reduced. Furthermore, harm to a "public corporation tends to be felt by all shareholders equally [whereas in] a private corporation it is frequently the opposite." ${ }^{, 1}$ It appears that the purposes behind the derivative action may be diluted in the context of a closely held corporation. ${ }^{52}$

In support of this, the Dickerson Report anticipates oppression being alleged more frequently in the context of a closely held corporation. ${ }^{53}$ According to Koehnen, the Dickerson Report approached the difference between derivative and oppression actions "as relating more to the nature of the corporation than to the nature of the claim." 54 Under this notion, the nature or size of a corporation is relevant to what claim may be brought.

It is true that the rationales supporting the derivative provision may be less important in the context of a small corporation. Nevertheless, the Dickerson Report states that the purpose of the derivative action "is to remedy a wrong done to the corporation, [and] therefore it applies to all corporations irrespective of size or distribution of shares." ${ }^{, 55}$ It follows that the derivative action remains relevant in the context of a closely held corporation. Furthermore, and as detailed more fully below, the derivative and oppression provisions do not draw a distinction based on the nature of the corporation. ${ }^{56}$ The better view is that the size or nature of the corporation is not relevant in ascertaining whether the claim is personal or derivative.

See Part II.C.2, below.

Malata, supra note 40 at para 39.

Koehnen, supra note 5 at 449.

Tersigni, supra note 39 at para 26.

Dickerson Report, supra note 9 at para 484.

Koehnen, supra note 5 at 448.

Dickerson Report, supra note 9 at para 484.

See Part II.C.2.e, below. 


\section{THE OPPRESSION PROVISION DOES \\ Not EMBRACE DERIVATIVE HARM}

\section{a. Statutory Analysis}

On balance, the weight of judicial authority suggests that derivative claims cannot proceed by way of oppression. Although the plain wording of the oppression provision introduces uncertainty, reading the two provisions in unison supports the argument that an oppression action cannot be advanced for derivative harm.

The bare text of the oppression provision is not the end of the interpretive analysis as one must further consider "the history of the provision at issue, its place in the overall scheme of the Act, the object of the Act itself, and Parliament's intent both in enacting the Act as a whole, and in enacting the particular provision at issue. ${ }^{, 57}$ In Greenshield v. $R$, the Supreme Court stated: "The broad general rule for the construction of statutes is that a section or enactment must be construed as a whole, each portion throwing light, if need be, on the rest." 58 Therefore, to determine the limits of the oppression action, it cannot be analyzed in isolation.

In Pappas v. Acan Windows Inc., ${ }^{59}$ the Court acknowledged the significance of the derivative action within the broader $C B C A$. It also acknowledged the difficulty in examining who suffers harm as between the shareholder and the corporation. This awkwardness arises because "all harm to a corporation indirectly, if not directly, harms the shareholder." ${ }^{\circ 0}$ To respond to this, the Court held that:

The Legislature enacted the derivative action sections of the Act together with the oppression remedy sections, and they must have had a reason for so doing. I believe that reason was to maintain the principle that the company is a legal entity distinct from its shareholders and that the majority shareholders of a corporation should, as a general rule, be permitted to manage the affairs of the corporation through the directors selected by them. $^{61}$

This means that it is important to insist that the stakeholder show direct harm in order to maintain the separate legal existence of a corporation. The foregoing passage also confirms that by enacting two separate provisions, one governing derivative actions and one governing oppression actions, Parliament has signaled the need for a distinction between the two.

Similarly, in NPV Management Ltd. v. Anthony, ${ }^{62}$ the Court interpreted both provisions and held that the complainant was required to advance a derivative, rather than personal, claim. In reaching this conclusion, it was held that "in the absence of inconsistency, each legislative provision must be given effect ... if the facts support an action for oppression but the claim is derivative in nature, section 239 would be engaged and leave of the court to

Chieu $v$ Canada (Minister of Citizenship and Immigration), 2002 SCC 3 at para 34.

[1958] SCR 216 at 225.

(1991), 90 Nfld \& PEIR 126 (SC (TD)) [Pappas].

Ibid at para 67.

Ibid at para 107. See Ballard, supra note 47 at para 140.

2003 NLCA 41, leave to appeal to SCC refused, 29988 (22 April 2004). 
proceed would be required." ${ }^{63}$ Indeed, as the Ontario Court of Appeal noted in Rea, Parliament's response to the rule in Foss $v$. Harbottle "was to create two remedies, with two different rationales and two separate statutory foundations, not just one: a corporate remedy, and a personal or individual remedy." ${ }^{64}$ Such an interpretation gives full effect to the distinct derivative provision, which in turn helps define the scope of the oppression action.

Allowing corporate harm to be remedied through oppression would abrogate the derivative provision, because the threshold for bringing an oppression claim is lower than that of a derivative action. ${ }^{65}$ It is lower because an oppression action does not just grant a remedy where there has been "a violation of corporate legal rights." ${ }^{66}$ Rather, an oppression remedy may be granted when the complainants' reasonable expectations are unfairly disregarded ${ }^{67}$ It is not controversial to state that "[c]laiming oppression is easy. Only the low bar of unfairness must be overcome." ${ }^{\circ 8}$ Allowing derivative claims to be advanced by way of oppression would render the derivative action effectively meaningless because of the incentive to utilize the oppression provision's lower threshold.

However, the presence of a derivative claim does not necessarily preclude an oppression action. Rather, as was recognized in Hercules, the same facts may give rise to two causes of action. ${ }^{69}$ Even though remedying corporate harm requires a derivative action, a separate oppression claim may also be brought should the complainant suffer direct harm that is distinct from that suffered by the corporation. ${ }^{70}$ Importantly, this prevents the derivative provision from hindering the broad, equitable nature of the oppression remedy.

\section{b. Other Rationales Underlying the Derivative Provision}

The purposes of the derivative action previously mentioned, namely preventing strike suits and multiplicity of proceedings, support the argument that an oppression action cannot be used for derivative claims. There are two less obvious rationales that further support this position. First, remedial complications can arise when only one stakeholder is compensated. Second, the derivative provision facilitates legal action by expressly contemplating indemnification of a complainant's legal costs. The common thread through all of these rationales is the preservation of judicial and corporate resources.

Ibid at para 35. See also Koehnen, supra note 5 at 441.

Rea, supra note 5 at para 35 [emphasis in original]. See also Meditrust Healthcare Inc v Shoppers Drug Mart (2002), 61 OR (3d) 786 (CA); Hoskin v Price Waterhouse Ltd (1982), 37 OR (2d) 464 (H Ct J); Goldex Mines Ltd v Revill (1974), 7 OR (2d) 216 (CA) [Goldex Mines].

See Pappas, supra note 59 at para 110:

If the cause of action is one of an essentially derivative character, then, in my opinion, in order to give any meaning to the derivative claim sections of the Corporations Act, it is necessary to require that a claimant first obtain leave to commence the action .... To hold otherwise would be to subvert the principle that the company is a legal entity distinct from its shareholders.

Peterson, supra note 10 at 17.28 .

Malata, supra note 40 at para 34.

$B C E$, supra note 4 at para 56. See also Part II.A, above.

Girgis, supra note 15 at 486.

Hercules, supra note 23 at 214. See also Goldex Mines, supra note 64; Liu v Sung (1991), 82 DLR (4th) 283 (BCCA); Rea, supra note 5 at para 26.

See e.g. Acapulco Holdings Ltd v Jegen, 1997 ABCA 40. But see Pappas, supra note 59 at para 111: "If, however, it is not possible to clearly separate the personal and derivative claims then, I believe, that both those claims should be discontinued, where no leave has been obtained, unless the derivative claims are merely incidental to and clearly of secondary importance to the personal claims." 
Remedial complications may result where personal recovery is permitted for harm done to the corporation. ${ }^{71}$ Consider the case of a director misappropriating corporate assets. If a shareholder is permitted to bring a personal action for such wrongdoing, they may plead personal damages. The problem is that personal recovery could disproportionately favour the plaintiff while prejudicing other stakeholders. ${ }^{72}$ For example, the trade creditor who was negatively affected by the misappropriation may not obtain the benefits of the shareholder's action if the shareholder is able to recover personally. If other stakeholders have not commenced litigation, their interests may not be considered. ${ }^{73}$ In such a case, other stakeholders such as creditors, employees, and suppliers are left out in the cold.

Second, the indemnification of legal costs serves a crucial role in facilitating legal action where appropriate. Absent indemnification, rational economic actors may wait to see if another party's personal action is successful before pursuing their own. ${ }^{74}$ Put differently, other stakeholders may seek a free ride. As the Court in Seinfeld v. Coker remarked:

It is important for shareholders to bring derivative suits because these suits, filed after the alleged wrongdoing, operate as an ex post check on corporate behavior. If no incentive existed for shareholders to band together to bring these suits, they would very often not be brought. The reason is simple: for the group of shareholders, the benefits exceed the costs; for individual shareholders, the costs exceed the benefits in the vast majority of cases. ${ }^{75}$

Where a court orders damages be paid to the corporation, there would be a disincentive to bring legal action if the moving party was left uncompensated. Therefore, if damages are paid to the corporation, it is only logical that the moving party be indemnified. The CBCA, through the derivative provision, provides an incentive for stakeholders to hold corporate actors accountable while preventing other non-moving parties from receiving a free ride. ${ }^{76}$

These rationales highlight the importance of ensuring that the oppression action be prevented from advancing derivative claims. Indeed, these rationales "remain valid legislative objectives and concerns." 77 It follows that ignoring the distinction between personal and derivative claims would undermine these legislative purposes.

\section{c. Corporate Rights and Taking a Litigation Opportunity}

Simply put, the statutory derivative action respects the common law principle that "A cannot, as a general rule, bring an action against $\mathrm{B}$ to recover damages or secure other relief

MacIntosh, supra note 26 at 59.

Ibid at 60 .

Theoretically, a court would consider that other stakeholders may be impacted by the corporate misconduct and order the damages paid to the corporation. But this would appear to depend on one of the parties having pled that damages/relief be awarded to the corporation. This, in turn, gives rise to the multiplicity of proceedings problem outlined earlier.

74 See Edward M Iacobucci \& Kevin E Davis, "Reconciling Derivative Claims and the Oppression Remedy" (2000) 12 SCLR 87 at 95.

847 A (2d) 330 at 333 (Del Ct Ch 2000) [emphasis in original].

While a complainant could claim interim costs connected to an oppression action, pursuant to section 242(4), a separate application is required for such relief.

Rea, supra note 5 at para 37. See Khimji \& Viner, supra note 18 at $158-60$. 
on behalf of $\mathrm{C}$ for an injury done by $\mathrm{B}$ to $\mathrm{C} .{ }^{, 78}$ Where the corporation, rather than the stakeholder, suffers the direct harm and acquires a cause of action, the corporation is the proper plaintiff to pursue its claim. Allowing the oppression provision to embrace derivative harm results in the separate legal personality of the corporation being eroded because it undermines the fact that corporations hold exclusive rights. ${ }^{79}$

An analogy can be drawn regarding directors' restrictions on taking corporate opportunities. A director is not permitted to take an opportunity that belongs in fairness to the corporation. ${ }^{80}$ Similarly, a complainant should not be permitted to advance a right or cause of action that belongs to the corporation. Apart from undermining the separate legal existence of the corporation, this amounts to taking a litigation opportunity and could prejudice other stakeholders. It is true that a stakeholder may not owe a fiduciary duty to the corporation and may be altogether different than a director. Nevertheless, there is no apparent reason to draw a conceptual distinction between the two. In the case of corporate harm, therefore, it is the corporation that must pursue the claim.

\section{d. Section 242(3)(q) of the Business Corporations Act}

Interestingly, Alberta and British Columbia's corporate law statutes provide relief for those who have improperly chosen to advance an oppression action for a claim that is derivative. ${ }^{81}$ Upon alleging oppression, section 242(3)(q) of the Alberta Business Corporations Act contemplates an "order granting permission to the applicant to ... bring an action in the name and on behalf of the corporation." 82 This indicates that the legislature foresaw complainants improperly advancing a derivative claim as an oppression action. In response, the legislature granted courts the ability to efficiently move a complainant into the proper lane. While it is uncertain how this provision would operate, the Alberta Law Reform Institute Report notes that "[i]ts purpose is to avoid a situation in which an application must be dismissed merely because the applicant made the wrong choice of procedure." ${ }^{\prime 3}$ Evidently, this provision introduces an element of forgiveness while underscoring the importance of the complainant advancing the appropriate action.

\section{e. The Size or Nature of the Corporation is Not Relevant}

The distinction between large and small corporations, or the nature of the corporation, is only relevant for determining the reasonable expectations created under branch one of the $B C E$ test. This is supported by commentary contained in the Dickerson Report and the fact that the nature of the corporation is not contemplated in the relevant provisions of the CBCA.

Prudential Assurance Co Ltd v Newman Industries Ltd (No 2), [1982] Ch 204 (CA) at 210. See Hercules, supra note 23 at 212.

1043325 Ontario Ltd v CSA Building Sciences Western Ltd, 2012 BCSC 1058 at para 20.

Canadian Aero Service Limited v O'Malley, [1974] SCR 592; Matic v Waldner, 2016 MBCA 60; Harris $v$ Leikin Group Inc, 2014 ONCA 479 at para 73.

See e.g. Business Corporations Act, SBC 2002, c 57, s 227(3)(r). Unfortunately, the CBCA does not contain such a provision.

Business Corporations Act, RSA 2000, c B-9, s 242(3)(q) [ABCA].

Institute of Law Research and Reform, Proposals for a New Alberta Business Corporations Act, Report No 36, vol 2 (Edmonton: Institute of Law Research and Reform, 1980) at 329. 
The Court in BCE stated: "The size, nature and structure of the corporation are relevant factors in assessing reasonable expectations." 84 It was similarly noted that "courts may accord greater latitude to the reasonableness of expectations formed in the context of a small, closely held corporation, rather than those relating to interests in a large, public corporation." ${ }^{95}$ These statements indicate that the size or nature of the corporation is considered when determining the objectively reasonable expectations of the complainant.

The Dickerson Report states that the oppression remedy will be "invoked most frequently - but not always - in respect of a corporation the shares of which are held by only a relatively small number of persons." 86 The foregoing is merely a recognition that oppression will be invoked more regularly in the context of a closely held corporation. This is likely due to the personal relationships and corresponding "reasonable expectations" that arise by interacting with a small corporation. This comment in the Dickerson Report does not make the nature of the corporation a factor in analyzing whether an oppression action may be advanced for derivative harm.

The Dickerson Report also notes that it did not preserve "the traditional private-public corporation dichotomy." ${ }^{87}$ Instead, the Dickerson Report "defined 'corporation' in different ways in different parts of the Draft Act where it seemed necessary or desirable to create a distinction." ${ }^{\prime 8}$ The $C B C A$ provisions that govern derivative and oppression actions do not define which type of corporation may proceed under each action. In other words, while the derivative action rationales may be less important in the context of a closely held corporation, Parliament did not think it was necessary to draw a distinction along such lines. Therefore, apart from the reasonable expectations created in the context of a closely held corporation, the size or nature of the corporation is not relevant in determining whether a complainant may proceed by way of an oppression action for derivative harm.

\section{The Supreme Court OF CANAdA DECISION IN BRUNETTE}

On 7 December 2018, the Supreme Court rendered its decision in Brunette. This case is important because it reaffirms that corporations, as separate legal persons, hold exclusive rights of action. Owing to this, the Court held that shareholders cannot advance a personal claim that belongs to the corporation. It follows that the distinction between derivative and oppression actions is mandatory.

While Brunette is from Quebec, it would be a mistake to assume that the case is confined to the civil law. As Justice Rowe, writing for the majority, expressly stated: "In certain cases, the civil law produces a conclusion similar to that which would arise under the common law.

BCE, supra note 4 at para 74 .

Ibid at para 109.

Dickerson Report, supra note 9 at para 484 [emphasis added].

Ibid at para 36 .

Ibid. 
This is one such case." ${ }^{\prime 89}$ If properly recognized, Brunette will refine corporate litigation by requiring plaintiffs to show direct or distinct harm when bringing an oppression action. ${ }^{90}$

The relevant facts are as follows. A trust owned all the shares of a holding company. The holding company, in turn, owned a group of corporations (Groupe Melior). In the past, Groupe Melior had successfully "owned, renovated, and operated seniors' residences." Unfortunately, Groupe Melior received faulty tax advice that resulted in bankruptcy for most of the corporations. The trustees, on behalf of the trust, then brought "contractual and extra contractual" actions against the lawyers and accountants that rendered the tax advice to Groupe Melior. ${ }^{92}$

At the Supreme Court, the trustees argued that the common law rule barring shareholder recovery had no place in the civil law. ${ }^{93}$ The Supreme Court, however, held that this argument "misses the mark" $"$ because the civil law had consistently produced a similar result. Under the Civil Code of Québec, corporations "have full enjoyment of civil rights" and the "capacity to exercise all their rights." 95 Shareholders are distinct legal persons and as such, cannot usurp the rights of action that belong to the corporation. ${ }^{96}$

While the Supreme Court insisted on the distinction between personal and corporate harm, it was noted that shareholders may bring an action "if they can demonstrate (1) a breach of a distinct obligation, and (2) a direct injury that is distinct from that suffered by the corporation in question." ${ }^{, 97}$ In this case, the contracts for service were only between the tax advisors and Groupe Melior, not the trust. Additionally, the plaintiffs did "not disclose the breach of an independent legal obligation owed to [the trust]. ${ }^{, 98}$ There was no evidence that the trust suffered a loss that was distinct from that of Groupe Melior, and therefore, the appeal was dismissed. ${ }^{99}$

Theoretically, this result does not leave the trustees without recourse. Rather, the availability of a derivative action was highlighted as follows: "If shareholders wish to ensure that a corporation exercises its rights, they may do so by means of a derivative action in the corporation's name: $[C B C A]$... s. 239." ${ }^{100}$ Here, however, a derivative action was cold

Brunette, supra note 7 at para 24.

Although it may be obvious, it is important to emphasize that an oppression claim is a personal action. See Pasnak v Chura, 2004 BCCA 221 ("[t]he authorities are clear that a shareholder must show direct and special harm in order to maintain a personal action for oppression, otherwise he must seek leave to bring a derivative action in the name of the company" at para 5); Ford Motor, supra note 38 ("an oppression action is a personal remedy premised upon there being prejudice to the interests of the complainant shareholder" at para 240); Pappas, supra note 59 at para 106; Walker v Betts, 2006 BCSC 128 at para 81; Hundal v Border Carrier Ltd, 2011 BCSC 1703 at para 7 [Hundal]; McGuinness, supra note 5 at $\$ 22.46$.

Brunette, supra note 7 at para 2.

Ibid at para 34.

Ibid at para 24.

Ibid.

Arts 301, 303 CCQ.

Brunette, supra note 7 at para 28.

Ibid at para 51.

Ibid at para 35 .

Ibid at para 50 .

Ibid at para 53. 
comfort owing to the bankruptcy of the corporations. ${ }^{101}$ Nevertheless, this comment is important because it illustrates the Supreme Court's insistence that a derivative action be used when no direct harm is suffered by the stakeholder.

Brunette ultimately supports the idea that a complainant cannot advance a personal claim for indirect harm. If the harm suffered by the stakeholder is merely a result of the harm suffered by the corporation, the action must proceed derivatively.

\section{ThE DiRECT HARM REQUIREMENT}

The Supreme Court in Brunette was clear. To bring a personal action, it is necessary for a complainant to show the existence of a direct injury that is distinct from that suffered by the corporation. ${ }^{102}$ The fact that both derivative and personal actions are available is not determinative. ${ }^{103}$ Instead, one must consider the nature of the damage when discerning the distinction between the two actions. ${ }^{104}$ An important question then follows: what constitutes direct harm?

The answer is complicated when considered alongside other Supreme Court jurisprudence. In $B C E$, the Supreme Court famously gave examples of conduct that would fall within the oppression provision. The Supreme Court cited the following as examples of such conduct:

[S]queezing out a minority shareholder, failing to disclose related party transactions, changing corporate structure to drastically alter debt ratios, adopting a "poison pill" to prevent a takeover bid, paying dividends without a formal declaration, preferring some shareholders with management fees and paying directors' fees higher than the industry norm. ${ }^{105}$

Other examples caught by the provision included: "favouring a director by failing to properly prosecute claims, improperly reducing a shareholder's dividend, or failing to deliver property belonging to the claimant." 106

The problem with some of these examples is that they do not readily disclose direct harm. For example, "failing to disclose related party transactions" and "failing to prosecute claims"

Upon bankruptcy, a derivative action becomes unavailable because all property vests in the trustee in bankruptcy. See Bankruptcy and Insolvency Act, RSC 1985, c B-3 (property means any type of property... and includes ... things in action,"s 2). See Brunette, supra note 7, where the Supreme Court also pointed to the distortion of bankruptcy priorities that would occur if the trust could personally recover (" $[t]$ o allow shareholders to gain an independent right of action prior to this distribution for injuries suffered by the bankrupt corporation would be to upend the usual priorities of the Bankruptcy and Insolvency Act" at para 53).

Brunette, ibid at para 31. See Shefsky v California Gold Mining Inc, 2016 ABCA 103 at para 40 [Shefsky]; Rea, supra note 5 at paras 33-35; McGuinness, supra note 5 ("[t]he shareholder or other complainant seeking to establish oppression must show direct and special harm" at 312). The requirement for direct harm is not novel to the common law. Indeed, "[r]elatively few causes of action ... are actionable without proof of damage or other harm" at $\S 21.136$ ). See also Furry Creek Timber Corp v Laad Ventures Ltd (1992), 75 BCLR (2d) 246 at para 16 (SC); Hundal, supra note 90 at para 7. McGuinness, ibid at $\S 22.47$. Given the uncertainty in the law, counsel should institute derivative proceedings "whenever a claim might involve a wrong done to the corporation rather than ... proceed on the assumption that no leave is required" (ibid at $\S 22.49$ ).

105 BCE, supra note 4 at para 93, citing Koehnen, supra note 5 at 82-83. 
would appear typically derivative in nature. ${ }^{107}$ Unless the Supreme Court intended to collapse the distinction between derivative and oppression actions, it is not apparent how such claims could be advanced as oppression.

It would appear plausible that the BCE Supreme Court did intend to collapse the distinction, given the nature of the examples and the Supreme Court's reliance on Koehnen. ${ }^{108}$ Indeed, Madam Justice Newbury in Icahn Partners LP v. Lions Gate Entertainment Corp. commented on the inherent difficulty posed by the BCE examples, stating:

\begin{abstract}
At least prior to $B C E$, I would have thought, for example, that the decision of a board to pay directors' fees "higher than the industry norm" would not be regarded as the basis for an oppression claim, but as a breach of duty owed to the corporation. However, the Supreme Court of Canada cited this as an example of unfairly prejudicial conduct at para. 93 of $B C E$. Whether the Court thereby intended to signal that derivative actions (for breach of fiduciary duty) and oppression claims should in its view be collapsed into one category, despite their different treatment in Canadian corporate legislation, remains to be seen. ${ }^{109}$
\end{abstract}

However, the recent British Columbia Court of Appeal decision in Jaguar did not view $B C E$ as collapsing the distinction between derivative and oppression actions. In relying on the requirement that the harm be distinct from that suffered by the corporation, it was helpfully noted that:

[T] here are scenarios where $B C E$ 's examples, such as paying directors' fees higher than industry norms, could result in a shareholder experiencing distinct harm and therefore reconcile $B C E$ with the other authorities.... [T] he payment of a director's fee may be in breach of an expectation that all monies would be paid out of the corporation to the shareholders in proportion to the shares held (BCE, para. 76). This would be a distinct harm as paying a director's fee would not only affect the company but separately and distinctly harm the other shareholder who alone would not receive a fee. ${ }^{110}$

Jaguar therefore allows both BCE and Brunette to be reconciled because the examples citied in $B C E$ only fall within the oppression provision if direct or distinct harm is present.

In order to discern the distinction between personal and corporate harm, a sample of cases have been selected that intersect with (1) a drop in the value of shares, (2) squeezing out a minority shareholder, (3) failing to disclose related party transactions, and (4) excessive management fees. In discussing these examples and the corresponding cases, the objective is to show how direct harm was present on the facts and therefore how a personal action was (or could have been) successful. Notably, these examples demonstrate how a bright line distinction between oppression and derivative claims can still flexibly respond to complex corporate disputes.

Under section 122(1)(a) of the $C B C A$, failing to disclose related-party transactions and failing to prosecute claims could be considered a breach of fiduciary duty.

See $B C E$, supra note 4 at paras 54, 58, 65, 67, 92-94.

2011 BCCA 228 at para 72.

Jaguar Financial Corporation v Alternative Earth Resources Inc, 2016 BCCA 193 at para 184 [Jaguar]. 


\section{A. Drop In The VAlUe OF Shares}

Generally, a drop in the value of shares is correctly cited as an example where no personal harm is suffered. ${ }^{111}$ The case of Houle $v$. Canadian National Bank, ${ }^{112}$ however, gives a situation where shareholders successfully claimed the loss in the value of their shares. This case was followed by the Supreme Court in Brunette and relied on for the proposition that distinct harm must be present to advance a personal claim.

Houle is from Quebec and involved a closely held corporation. The corporation and the bank had been doing business for 50 years. The corporation then requested that the bank increase its line of credit, which resulted in the bank engaging in a closer inspection of the company's affairs. Upon a verbal report being provided, the bank decided to recall the loan and realize on its security. Remarkably, "[t]he time span from the first notification of the imminent recall of the loan to the liquidation of the assets was three hours." 113

Unfortunately, this all occurred while the shareholders were in the midst of negotiations to sell their shares. The bank's sudden liquidation of company assets resulted in the shareholders receiving substantially less than their original asking price. Clearly then, all shareholders suffered the same loss.

The Supreme Court first held that the bank had breached its contractual duties to the corporation. ${ }^{14}$ However, the shareholders could not recover for such a breach. Notwithstanding the personal dealings the shareholders had with the bank, the Supreme Court relied on Justice Wilson in Kosmopoulos and held: "One cannot limit his responsibility by investing in a company and still consider as a personal damage any damage caused to such company; the shareholder's damage is indirect." 115 Therefore the loss from the breach of contract was not recoverable personally.

However, the shareholders were successful in their personal action on the basis of "delictual liability." 116 This appears akin to common law liability in negligence and was independent of any contractual obligations owed to the corporation. ${ }^{117}$ Fault was found because the bank knew of the imminent sale of shares and therefore had an obligation to "provide a reasonable delay before ... taking possession and liquidating the assets." 118 The damages were distinct from that suffered by the corporation because the shareholders "had a direct, personal, financial interest at stake." ${ }^{119}$ Causation was also present on the facts and therefore, the personal action was successful. ${ }^{120}$

See 1043325 Ontario Ltd v CSA Building Sciences Western Ltd, 2016 BCCA 258 at para 74 [CSA Building], leave to appeal to SCC refused, 37186 (19 January 2017); Khela $v$ Phoenix Homes Limited, 2015 BCCA 202 at paras 41,47; Shefsky, supra note 102 at para 46; BCE, supra note 4 at para 163. [1990] 3 SCR 122 [Houle].

Ibid at 132 .

Ibid at 176 .

Ibid at 179, citing Kosmopoulos, supra note 2 at 11.

Houle, ibid at 187.

See McGuinness, supra note 5 at $\$ 22.44$.

Houle, supra note 112 at 185.

Ibid at 186.

Ibid at 187 . 
In Brunette, it was emphasized that Houle should not be treated as an exception, but rather as support for the proposition that shareholders can bring a claim where direct harm is present. ${ }^{121}$ While this result may appear initially surprising, Houle demonstrates that in certain circumstances, a shareholder may bring an action for a loss in the value of their shares.

\section{B. SQueEzing OUT A MinORIty SHAREHOLder (NON-PAYMENT OF DIVIDENDS)}

In the oft-cited decision of Ferguson, ${ }^{122}$ the Ontario Court of Appeal held that oppression had occurred in the context of a squeeze out. For the purposes of this article, it suffices to highlight the following facts. First, there were three couples initially involved in the corporation. The husbands held the common shares, and the wives held the class B shares. The class B shares were non-voting and had certain dividend rights. ${ }^{123}$ After Mrs. Ferguson had devoted substantial time and effort to the success of the company, Mr. and Mrs. Ferguson separated. Shortly thereafter, the company became profitable. ${ }^{124}$ Even though the corporation was able to pay dividends, the now separated Mr. Ferguson put "heavy pressure on the company" not to do so. ${ }^{125}$

Subsequently, a resolution was proposed whereby all the class B shares would be converted into class A shares. The class A shares were non-voting, limited to 9 percent cumulative dividends, and, after a certain date, redeemable by the company at " $\$ 175$ per share." ${ }^{126}$ Along with Mrs. Ferguson, this resolution applied to the other class B shareholders. However, the crucial difference was that the common shares were held by the husbands of the other class B shareholders. As such, even if the other wives' class B shares were redeemed, the profits would continue to accrue to them by virtue of their continued marriage. In other words, the other class B shareholders would continue to share in the growth of the now profitable company. This resulted in Mrs. Ferguson suffering direct harm.

The Court summarized its holding on direct harm by stating:

[T] he payment of moneys now as a capital payment, which moneys on the evidence ought to have been paid by way of dividends over the years the appellant's non-redeemable shares are now to be redeemed and those in control of the company will be rid of her. She is the only one so affected. All of the other class B shareholders hold an equal number of common shares personally or through their spouses. ${ }^{127}$

Therefore, Mrs. Ferguson's true economic position was subject to direct harm that was distinct from that suffered by the other class B shareholders. This is an important point. It is not the individual's position in a certain class that is subject to the distinct harm analysis. Rather, this case suggests that the oppression analysis examines the individual in their aggregate interaction with the corporation when inquiring into the nature of the harm

Supra note 7 at para 30.

Supra note 13 .

Ibid at 131 .

Ibid at 133 .

Ibid.

Ibid at 136 .

Ibid at 138 [emphasis added]. 
suffered. As such, the oppression action was successful owing to the distinct economic harm suffered by Mrs. Ferguson.

\section{Failing to Disclose Related Party Transactions}

The case of $R e a^{128}$ dealt with alleged misappropriation of corporate funds in the context of a publicly traded corporation. The plaintiff, Mr. Rea, was one of Martinrea's principal founders, as well as a director and a significant minority shareholder. The defendants consisted of directors, one executive, and a supplier.

The Ontario Court of Appeal addressed whether the action could proceed personally, or whether it was required to proceed derivatively. After canvassing the case law and acknowledging the overlap between personal and derivative actions, it was held that a derivative action was required. ${ }^{129}$

The Court distinguished cases where oppression could proceed in the face of wrongs done to the corporation by pointing out that in this case the harm was merely indirect. In other words, the harm to Rea was only a result of the harm suffered by the corporation. ${ }^{130}$ In order to claim oppression, there needed to be a "particularized allegation of any wrong done to the interests of the plaintiffs themselves ... as opposed to a wrong affecting ... the collectivity of shareholders as a whole." 131 Here, given that no direct or distinct harm was pled, the action was dismissed.

In contrast, and as discussed earlier, the case of Malata ${ }^{132}$ has been understood to soften the distinction between oppression and derivative claims. Indeed, the Court in Malata expressly stated, "[T]here is not a bright-line distinction between the claims that may be advanced under the derivative action section of the Act and those that may be advanced under the oppression remedy provisions." 133 Unfortunately, this statement about a lack of distinction between oppression and derivative actions has resulted in confusion and was not required to reach the same conclusion.

In Malata, a minority shareholder and creditor (Malata HK) brought an oppression action against another minority shareholder (Mr. Jung). Apart from being a minority shareholder, Jung also served as a director. The claim was based on a breach of the shareholders' agreement and a failure to act honestly and in good faith as a director of Malata. ${ }^{134}$

Apart from both parties sharing the status of minority shareholders, there were grounds for finding that Malata HK was subject to direct or distinct harm. Malata HK did not have the benefit of managing the business, whereas Jung was a director. Furthermore, Malata HK 
was a "major creditor of Malata Canada." 135 It is therefore readily conceivable that distinct harm was suffered because the misappropriation would have resulted in Malata Canada's creditworthiness declining. ${ }^{136}$

While Malata appears correct in its result, the comments made in the case introduce a degree of uncertainty into the law. Nevertheless, the facts and corresponding results in both Rea and Malata indicate that personal harm is a necessary condition for bringing an oppression action.

\section{ExCessive Management Fees}

In CSA Building, ${ }^{137}$ the British Columbia Court of Appeal grappled with whether an action related to excessive management fees could proceed personally, rather than derivatively. As with many oppression cases, there were numerous allegations of wrongdoing. However, the focus here will remain on the management fees. ${ }^{138}$

The alleged oppression occurred in the context of a two-person corporation. The minority shareholder, Skene Co. (the principal being Mr. Skene), held 44 percent of the shares of CSA. Mr. Jeck held the remaining 56 percent of the shares of CSA and was its sole director.

Skene expected that an appropriate wage for Jeck was between $\$ 50,000$ to $\$ 75,000 .{ }^{139}$ In reality, Jeck had been paying himself well above this amount (the maximum reached was $\$ 634,262) .{ }^{140}$ It was recognized that these high management fees and self-dealing also constituted "a wrong to the corporation." 141 However, in reviewing the relevant authorities, the Court held that Skene Co. had "shown particular prejudice or damage, personal to itself, and should not be required to sue derivatively." "142 Also highlighted was the trial judge's finding that "Mr. Jeck had been motivated by the hope of buying Skene Co. out of CSA cheaply." 143

Again, the facts give rise to distinct harm. It is true that both Skene Co. and Jeck, as shareholders, would have suffered the same harm as a result of the excessive management fees. However, Skene Co., in its aggregate interaction with the corporation and as a nondirector, suffered direct harm because it alone did not receive the management fees. In holding that an oppression action was appropriate, it was determined that Skene Co. was personally entitled to 44 percent of any amount above $\$ 300,000$ that was paid as a management fee over the years in question. ${ }^{144}$

The foregoing examples show that direct harm is not necessarily difficult to demonstrate. Even where the harm appears to be borne by the corporation, these cases suggest that the

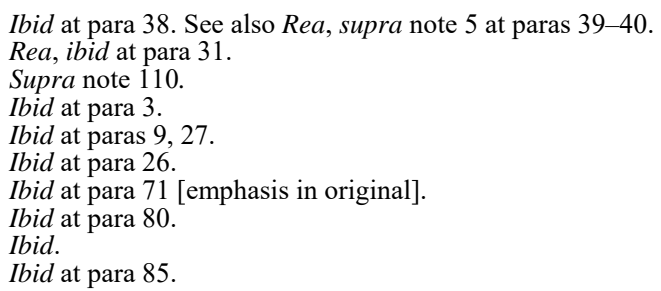


complainant may still be able to prove direct harm that is distinct from that suffered by the corporation. Put differently, combining the direct harm requirement with the current test for oppression still leaves enough flexibility for complainants to bring a successful oppression action. This properly respects the distinct provisions in the $C B C A$, while also maintaining a court's broad remedial discretion. Such a balance is in keeping with the legislative intent that underlies both provisions.

\section{Conclusion}

The oppression action cannot be used to advance derivative claims. This conclusion is supported by a statutory analysis, which includes consideration of the derivative provision and its accompanying rationales. Allowing oppression to remedy corporate harm effectively ignores a corporation's statutory capacity to hold exclusive rights. This in turn undermines the separate legal existence of a corporation. Similarly, allowing the oppression provision to embrace derivative harm amounts to taking a litigation opportunity and ought to be prohibited. The $A B C A$ supports this position through a unique provision that is aimed at directing complainants to pursue the proper action. Furthermore, while the nature of the corporation is important when assessing reasonable expectations, it is not relevant when discerning whether an action must proceed derivatively. Finally, the case law suggests direct harm that is distinct from that suffered by the corporation is necessary for bringing a personal oppression action. Insisting on evidence of direct harm will bring a more robust analysis to this area of the law, yielding positive results for corporate litigants.

It has been over ten years since $B C E$ was rendered. Unsurprisingly, the jurisprudence remains uncertain. Courts are often required to engage in both a lengthy analysis of the facts (given the nature of corporate disputes) and additionally, a lengthy analysis of the law. The results are decisions that "appear random and haphazard." 145 Given these realities, perhaps the best option is for the oppression provision to be refined through a statutory amendment. ${ }^{146}$ However, as a more incremental alternative, it may be prudent for the Supreme Court to revisit the issue of oppression and clarify the examples cited in BCE. When discussing the test for oppression, it is advisable to concurrently state that a complainant is required to show direct harm that is distinct from that suffered by the corporation. While this article has purported to show that direct harm is necessary when bringing an oppression action, the Supreme Court in BCE made no mention of this. Hopefully the Supreme Court will revisit this issue and bring greater clarity to this area of the law. 
[this page is intentionally blank] 